\title{
Random Walk in Emerging Asian Stock Markets
}

\author{
Muneer Shaik $^{1} \&$ S. Maheswaran ${ }^{2}$ \\ ${ }^{1}$ Research Scholar, Institute for Financial Management and Research, India \\ ${ }^{2}$ Senior Professor, Institute for Financial Management and Research, India \\ Correspondence: Muneer Shaik, Research Scholar, Institute for Financial Management and Research, \# 24, \\ Kothari Road, Nungambakkam, Chennai-600 034, India. E-mail: muneer.shaik@ifmr.ac.in
}

Received: October 17, 2016

Accepted: November 3, 2016

Online Published: December 14, 2016

doi:10.5539/ijef.v9n1p20

URL: http://dx.doi.org/10.5539/ijef.v9n1p20

\begin{abstract}
The random walk hypothesis is an important area of research in finance and many tools have been proposed to investigate the behaviour of the fluctuations in stock prices. However, a detail study on emerging Asian stock markets which employ the various unit root tests has not been done. In this paper, we employ six different unit root tests such as the Augmented Dickey and Fuller test (1979), Phillips and Perron test (1988), Kwiatkowski-Phillips-Schmidt-Shin test(1992), Dickey-Fuller GLS (ERS) test (1996), Elliot-Rothenberg-Stock Point-Optimal test (1996) and Ng and Perron (2001) unit root tests on 10 emerging Asian stock markets to detect for the presence of a random walk in stock prices. We have conducted the unit root tests during different sub-sample time periods of global financial crisis to check for robustness. To be specific, we have found that during the overall sample period (2001-2015) 8 out of 10 Asian stock markets and during the pre-crisis period (2001-2007) all the 10 Asian stock market prices do follow random walk according to the unit root tests under consideration. However, during the crisis \& post-crisis period (2008-2015) we have found only 5 out of 10 Asian markets follow the random walk movement based on unit root tests.
\end{abstract}

Keywords: unit root tests, random walk, weak-form efficiency, stock indices, emerging asian markets, global financial crisis

\section{Introduction}

The random walk hypothesis has been an important area of research in the academic literature and is well known that stock prices move uncertainly in an efficient market. The origins of efficient market can be traced back to the pioneering work of Bachelier (1900) and the empirical research work of Cowles (1933). In an efficient market, the prices will completely reflect all the available information. Fama (1970) classified the markets into three categories namely weak form, semi-strong form and strong form of market efficiency. In weak form market efficiency, the information set consists of only the history of past prices. In semi-strong form, the information set consists of all publicly available data whereas in strong form market efficiency, the information set incorporates all private data i.e. it includes all information known to any market participant.

The tests on market efficiency have important implications on trading strategies and in the development phase of the market. Hence it is very much essential for the investors and the policy makers to understand the efficiency of the stock markets. In a weak form efficient market, stock prices do follow random walks due to which it becomes impossible to predict the future stock prices based on the past stock price information set due to which no individual can outperform the market.

First, we contribute to the existing literature on detecting the presence of random walks in the movement of stock prices in the most important emerging Asian stock markets. Most of the studies have dealt on few Asian markets but in this paper we do an extensive empirical analysis by undertaking 10 emerging Asian stock markets namely \{India, China, Hong Kong, Taiwan, Malaysia, Thailand, Pakistan, Srilanka, Indonesia \& Philippines \}. Second, we employ six different unit root tests such as the Augmented Dickey-Fuller test (1979), Phillips-Perron test (1988), Kwiatkowski-Phillips-Schmidt-Shin (1992) test, Dickey-Fuller GLS (ERS) test, Elliot-Rothenberg-Stock Point-Optimal test (1996) and $\mathrm{Ng}$ and Perron (2001) unit root tests to detect for the presence of a random walk in stock prices. We conducted the tests by considering the intercept and also by including trend \& intercept in the test equation for 10 emerging Asian stock markets. Third, in order to check for robustness, we have also implemented the unit root tests for the emerging Asian stock markets during different sub-sample time periods. 
We have performed the analysis during pre-crisis period (2001-2007), crisis \& post-crisis period (2008-2015) and overall sample period (2001-2015). The period of study is most relevant to understand the impact of Asian stock markets with regards to the global financial crisis 2008.

The remainder of the paper is discussed as follows. Section 2 contains the literature review on the efficiency of the major Asian stock markets. Section 3 provides a description of the data and Section 4 discusses the methodology used in our paper. The results are dealt with in Section 5. The paper ends with some concluding remarks in Section 6.

\section{Literature Review}

We find an extensive literature on the study of random walk hypothesis or tests for weak form efficiency in the major developed markets. However, the available literature on the movement of random walk in the emerging Asian stock markets is scarce. Most of the studies have concentrated on a single Asian market than performing tests on the overall emerging markets as a whole. Chaudhuri (1991) finds Indian market does not seem to be efficient even in its weak form by undertaking serial correlation, Runs test for the period 1988-1990. Poshakwale (1996) studies Indian market from the period 1987-1994 by performing serial correlation, Runs test, KS test and found evidence of weak form efficiency. Laurence et al. (1997) studied China Market for the period 1993-1996 and found evidence of weak form efficiency by conducting the unit root tests.

Balkiz (2003) investigates Kuala Lumpur stock market weak-form efficient and finds that the market is not efficient in a weak form. Ashutosh (2005) finds evidence of weak form efficiency in the Indian market during the period 1996-2001 by doing serial correlation test. Worthington \& Higgs (2006) for both developed and Asian markets by using serial correlation, Runs test, Unit root tests (ADF, PP \& KPSS) and multiple variance ratio tests. Cooray et al. (2007) studied SAARC countries namely India, Srilanka, Pakistan and Bangladesh by using the unit root tests for the period 1996-2005 and supports weak form efficiency by ADF \& PP unit root tests while DF-GLS and ERS tests do not support. Islam et al. (2007) examine Thailand Stock market with data from 1975 to 2001 and find that the market is not efficient. Asma et.al (2008) conducted studies on Bangladesh market for the period 1988-2000 by autocorrelation test and indicates that daily returns are not random.

Gupta and Basu (2007) performed ADF, PP and KPSS unit root tests on Indian stock markets and results found that market is not weak form efficient for the period from 1991-2006. Mishra (2009) used ADF, PP unit root tests on Indian stock market for the period from 2001-2009 and find weak form inefficiency. Hamid et al. (2010) performed analysis on Asia-Pacific markets for the period from 2004-2009 and found that monthly prices do not follow random walks in all the markets. Nisar et al. (2012) studied four South Asian markets and found that none of the markets follow random-walk and hence are not weak form efficient for the period 1997-2011. Mishra (2012) performed analysis on five South Asian markets for the period 2005-2010 by using ADF, PP unit root tests and provide evidence that these markets are not weak form efficient. Paulo (2013) studied 9 Asian markets by using the daily data and performed unit root tests like ADF, PP and KPSS along with variance ratio test and finds evidence that the analyzed markets are not weak form efficient. Amer et al. (2014) studied 3 south Asian markets for the period from 2003-2011 on monthly \& weekly return indices and finds evidence that the markets are not weak form efficient by using ADF, PP unit root tests.

\section{Data Description}

The study is conducted empirically by using the daily data of stock market prices of major Asian stock indexes namely India, China, Hongkong, Malaysia, Taiwan, Thailand, Pakistan, Srilanka, Indonesia and Philippines. The closing prices of the daily stock market index data is collected from the source Bloomberg for three different sample period's i.e. the overall period (Jan2001-Mar2015), the pre-crisis period (Jan2001-Dec2007) and the crisis \& post-crisis period (Jan2008-Mar2015). The continuously compounded annual rate of return is measured using, $r_{t}=\ln \left(p_{t} / p_{t-1}\right)$ where $r_{t}$ the return, $\ln$ is is the natural $\log , p_{t}$ is the current price and $p_{t-1}$ is the previous price.

Figure 1 displays the time plots of the return and price series for 10 emerging Asian stock markets. Table 1, Panel A: shows the results for the overall sample period from Jan 2001 to Mar 2015. During this period, we find the lowest mean returns are in Hongkong (0.0001), whereas the highest mean returns are in Pakistan $(0.0009)$. The lowest minimum returns are in Thailand (-0.1723), as are the highest maximum returns in Srilanka (0.1829). The standard deviations of returns range from 0.0080 (Malaysia) to 0.0164 (China). We find the returns in Taiwan, Pakistan and China are the least volatile, with Srilanka, Philippines and Malaysia being the most volatile. Finally, The Jarque-Bera statistic and the corresponding p-values reject the null hypothesis that the daily distributions of 10 Asian market returns are normally distributed. 
Table 1, Panel B: shows the results for the sub-sample pre-crisis period from Jan 2001 to Dec 2007. During the pre-crisis period, we find the lowest mean returns are in Taiwan (0.0003), whereas the highest mean returns are for Pakistan (0.0013). The standard deviations of returns range from 0.0084 (Malaysia) to 0.0152 (China). We find Taiwan, Pakistan and Hongkong to be least volatile, with Srilanka, Philippines and Thailand being the most volatile. The Jarque-Bera statistic and the corresponding p-values reject the null hypothesis that the daily distributions of 10 Asian market returns are normally distributed.

Table 1, Panel C: shows the results for the sub-sample crisis \& post-crisis period from Jan 2008 to Mar 2015. During this period, we find the lowest mean returns are in China (-0.0002), whereas the highest mean returns are for Srilanka (0.0006). The standard deviations of returns range from 0.0076 (Malaysia) to 0.0174 (China). We find the returns in Taiwan, China and Pakistan are the least volatile, with Malaysia, India and Philippines being the most volatile. The Jarque-Bera statistic and the corresponding p-values reject the null hypothesis that the daily distributions of 10 Asian market returns are normally distributed.
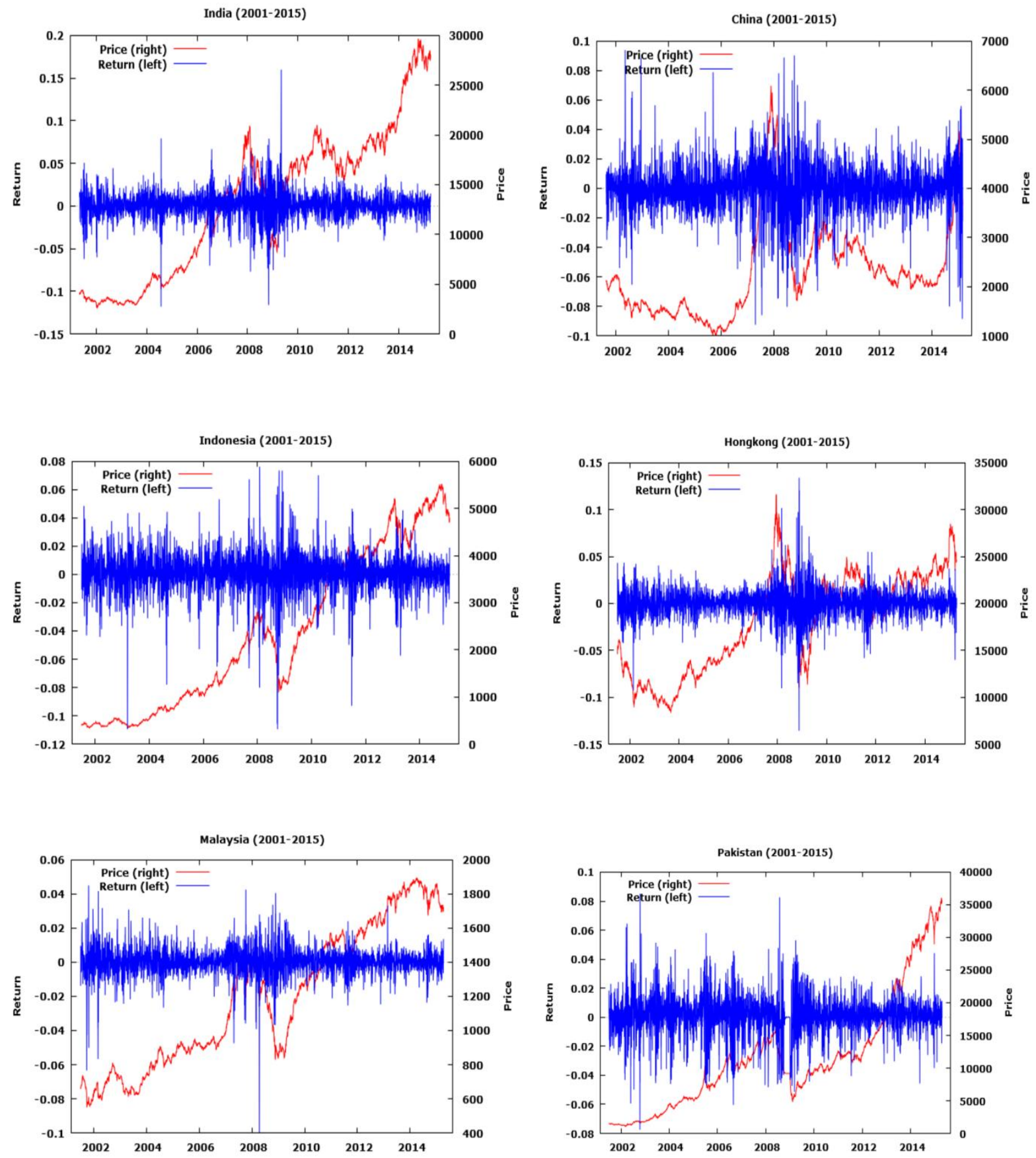

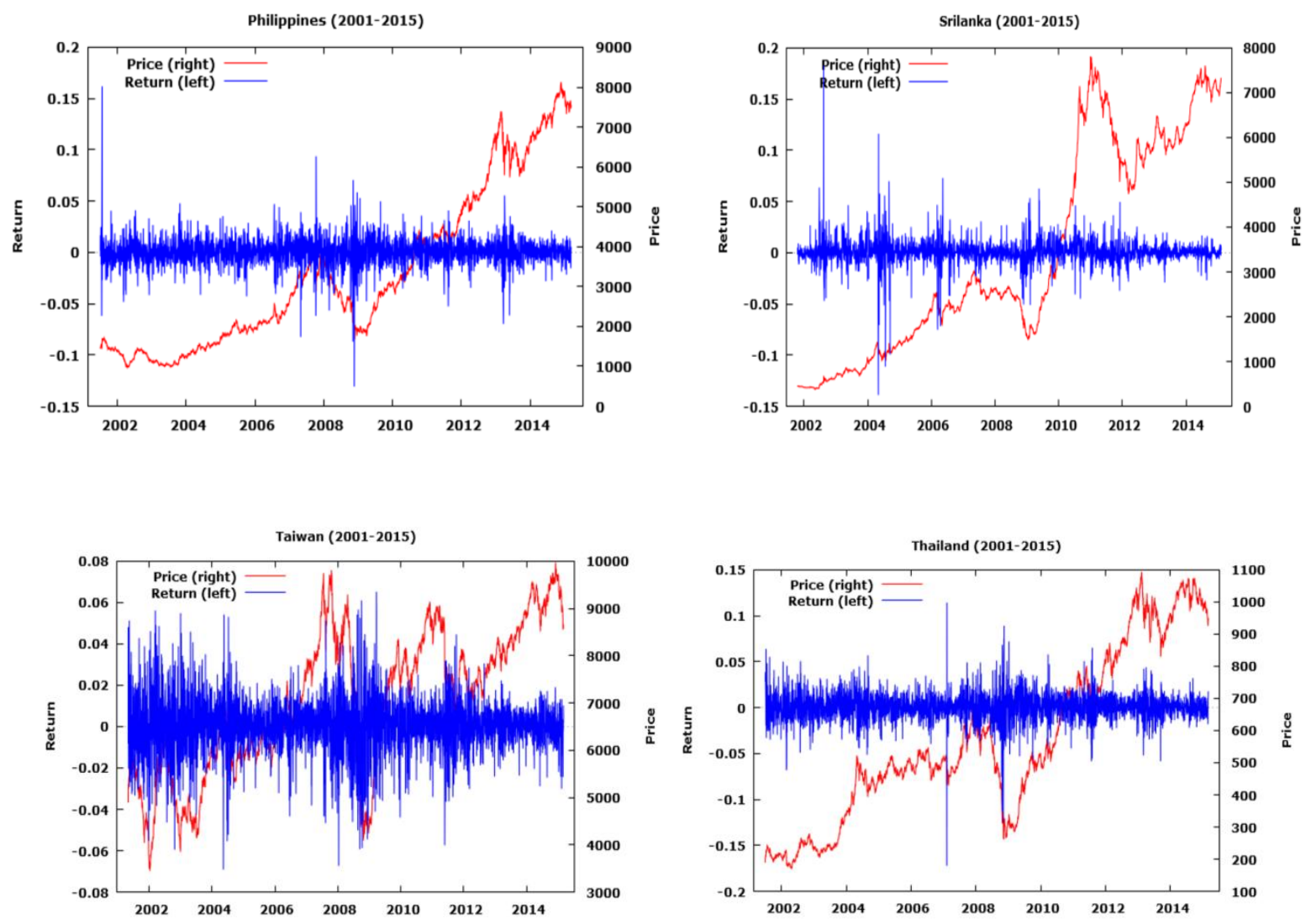

Figure 1. Time plot for return \& price series of Asian stock indices

Table 1. Descriptive statistics of Asian stock market index returns

\begin{tabular}{|c|c|c|c|c|c|c|c|c|c|c|}
\hline \multicolumn{5}{|c|}{ Panel A: Overall Sample Period (2001-2015) } & \multirow[b]{2}{*}{ Malaysia ? } & \multirow{2}{*}{\multicolumn{2}{|c|}{ Thailand Pakistan }} & \multirow[b]{2}{*}{ Srilanka } & \multirow{2}{*}{\multicolumn{2}{|c|}{ Indonesia Philippines }} \\
\hline & India & China & Hongkong ' & Taiwan $\mathrm{I}$ & & & & & & \\
\hline Mean & 0.0005 & 0.0002 & 0.0001 & 0.0002 & 0.0003 & 0.0005 & 0.0009 & 0.0008 & 0.0007 & 0.0005 \\
\hline Median & 0.0010 & 0.0006 & 0.0004 & 0.0005 & 0.0005 & 0.0005 & 0.0013 & 0.0005 & 0.0013 & 0.0005 \\
\hline Maximum & 0.1599 & 0.0940 & 0.1341 & 0.0652 & 0.0450 & 0.1143 & 0.0851 & 0.1829 & 0.0762 & 0.1618 \\
\hline Minimum & -0.1181 & -0.0926 & -0.1358 & -0.0691 & -0.0998 & -0.1723 & -0.0774 & -0.1390 & -0.1095 & -0.1309 \\
\hline Std. Dev. & 0.0151 & 0.0164 & 0.0151 & 0.0136 & 0.0080 & 0.0152 & 0.0136 & 0.0121 & 0.0141 & 0.0131 \\
\hline Skewness & -0.1252 & -0.2532 & -0.0209 & -0.1917 & -0.9700 & -0.5779 & -0.3001 & 0.3211 & -0.6807 & -0.0424 \\
\hline Kurtosis & 11.0044 & 7.1818 & 11.8501 & 5.6657 & 15.1137 & 12.7316 & 6.3845 & 32.6616 & 9.6916 & 15.6079 \\
\hline Jarque-Bera & 9713.56 & 2609.14 & 11735.90 & 1091.59 & 22531.93 & 14262.08 & 1773.191 & 127375.80 & 6899.46 & 23666.14 \\
\hline Probability & $0.0000^{*}$ & $0.0000^{*}$ & $0.0000 *$ & $0.0000^{*}$ & $0.0000^{*}$ & $0.0000 *$ & $0.0000^{*}$ & $0.0000^{*}$ & $0.0000^{*}$ & $0.0000^{*}$ \\
\hline Observations & 3635 & 3529 & 3596 & 3612 & 3593 & 3564 & 3602 & 3473 & 3551 & 3573 \\
\hline
\end{tabular}

Panel B: Pre Crisis Period (2001-2007)

$\begin{array}{lrrrrrrrrrrr} & \text { India } & \text { China } & \text { Hongkong Taiwan Malaysia Thailand Pakistan Srilanka Indonesia Philippines } \\ \text { Mean } & 0.0009 & 0.0005 & 0.0004 & 0.0003 & 0.0004 & 0.0007 & 0.0013 & 0.0010 & 0.0011 & 0.0005 \\ \text { Median } & 0.0016 & 0.0006 & 0.0005 & 0.0002 & 0.0006 & 0.0003 & 0.0022 & 0.0008 & 0.0015 & 0.0001 \\ \text { Maximum } & 0.0793 & 0.0940 & 0.0576 & 0.0561 & 0.0450 & 0.1143 & 0.0851 & 0.1829 & 0.0673 & 0.1618 \\ \text { Minimum } & -0.1181 & -0.0926 & -0.0929 & -0.0691 & -0.0634 & -0.1723 & -0.0774 & -0.1390 & -0.1093 & -0.0825 \\ \text { Std. Dev. } & 0.0143 & 0.0152 & 0.0125 & 0.0144 & 0.0084 & 0.0152 & 0.0151 & 0.0144 & 0.0136 & 0.0132 \\ \text { Skewness } & -0.6293 & -0.0060 & -0.2436 & -0.0982 & -0.6588 & -0.6253 & -0.3542 & 0.2936 & -0.6994 & 0.9409 \\ \text { Kurtosis } & 8.0635 & 7.4860 & 6.2006 & 4.9292 & 10.0258 & 15.2525 & 5.6689 & 32.3722 & 8.0642 & 18.7767 \\ \text { Jarque-Bera } & 1991.85 & 1412.89 & 753.77 & 271.38 & 3672.69 & 10832.92 & 547.42 & 59623.65 & 1959.75 & 18123.40 \\ \text { Probability } & 0.0000^{*} & 0.0000^{*} & 0.0000^{*} & 0.0000^{*} & 0.0000^{*} & 0.0000^{*} & 0.0000^{*} & 0.0000^{*} & 0.0000^{*} & 0.0000^{*} \\ \text { Observations } & 1756 & 1685 & 1726 & 1732 & 1725 & 1714 & 1723 & 1658 & 1704 & 1723\end{array}$




\begin{tabular}{|c|c|c|c|c|c|c|c|c|c|c|}
\hline \multicolumn{5}{|c|}{ Panel C: In \& Post Crisis Period (2008-2015) } & \multirow[b]{2}{*}{ Malaysia } & \multirow{2}{*}{\multicolumn{2}{|c|}{ Thailand Pakistan }} & \multirow[b]{2}{*}{ Srilanka } & \multirow{2}{*}{\multicolumn{2}{|c|}{ Indonesia Philippines }} \\
\hline & India & China & Hongkong & Taiwan & & & & & & \\
\hline Mean & 0.0002 & -0.0002 & -0.0001 & 0.0000 & 0.0001 & 0.0002 & 0.0005 & 0.0006 & 0.0003 & 0.0004 \\
\hline Median & 0.0005 & 0.0005 & 0.0003 & 0.0007 & 0.0003 & 0.0005 & 0.0005 & 0.0003 & 0.0011 & 0.0010 \\
\hline Maximum & 0.1599 & 0.0903 & 0.1341 & 0.0652 & 0.0406 & 0.0892 & 0.0825 & 0.0626 & 0.0762 & 0.0706 \\
\hline Minimum & -0.1160 & -0.0886 & -0.1358 & -0.0674 & -0.0998 & -0.1256 & -0.0513 & -0.0511 & -0.1095 & -0.1309 \\
\hline Std. Dev. & 0.0158 & 0.0174 & 0.0172 & 0.0128 & 0.0076 & 0.0151 & 0.0119 & 0.0095 & 0.0146 & 0.0130 \\
\hline Skewness & 0.2375 & -0.3852 & 0.0748 & -0.3217 & -1.3684 & -0.5358 & -0.2379 & 0.2460 & -0.6560 & -1.0038 \\
\hline Kurtosis & 12.7525 & 6.7950 & 12.0300 & 6.5671 & 21.7726 & 10.3959 & 7.0758 & 8.5125 & 10.7473 & 12.4082 \\
\hline Jarque-Bera & 7460.10 & 1151.54 & 6351.72 & 1028.62 & 27997.29 & 4302.63 & 1317.62 & 2315.09 & 4749.00 & 7129.74 \\
\hline Probability & $0.0000^{*}$ & $0.0000^{*}$ & $0.0000^{*}$ & $0.0000 *$ & $0.0000^{*}$ & $0.0000^{*}$ & $0.0000^{*}$ & $0.0000^{*}$ & $0.0000^{*}$ & $0.0000^{*}$ \\
\hline Observations & 1878 & 1843 & 1869 & 1879 & 1867 & 1849 & 1878 & 1814 & 1846 & 1849 \\
\hline
\end{tabular}

* means significant at $1 \%$ level of significanceSource:Developed by authors

\section{Methodology}

In a stationary time series, the mean and auto-covariance are independent of time. However, for a non-stationary time series, the variance increases over time. Random walk is the common example of a non-stationary time series where,

$$
z_{t}=z_{t-1}+\varepsilon_{t}
$$

where ' $\varepsilon$ ' is a stationary random error term. The random walk is a difference stationary series since the first difference of $y$ is stationary:

$$
z_{t}-z_{t-1}=(1-L) z_{t}=\varepsilon_{t}
$$

A difference stationary series is a random walk and is said to be integrated and is represented as I(d) where $d$ is the order of integration or the number of unit roots present to make the series stationary. For example, I (0) represent a stationary series with no unit root. I (1) represent stationary series with 1 unit root. Hence unit root is used as a standard method to check the stationary of a time series.

Now let us look at a simple Auto Regressive AR (1) process mentioned as below,

$$
z_{t}=\rho z_{t-1}+y_{t}^{\prime} \delta+\varepsilon_{t}
$$

Where $\rho$ and $\delta$ are parameters to be estimated, $\varepsilon_{t}$ is random disturbance term and $y_{t}$ is the independent term which can have a constant, a trend or both constant and a trend. A series $z$ is said to be non-stationary if the absolute value of the estimated parameter $\rho$ is greater than or equal to 1 . The variance of the non-stationary time series increases with time and nears infinity. Whereas, a series is said to be (trend) stationary, if the absolute value of the estimated parameter $\rho$ is strictly less than 1 .

\subsection{The Augmented Dickey-Fuller (ADF) Test}

In this test, the $\mathrm{AR}(1)$ process mentioned in equation (3) is estimated by removing $z_{t-1}$ from both sides of the equation as below.

$$
\Delta z_{t}=\alpha z_{t-1}+y_{t}^{\prime} \delta+\varepsilon_{t}
$$

where $\alpha=\rho-1$. We define the null and alternative hypotheses as,

$$
H_{O}: \alpha=0, H_{1}: \alpha<0
$$

and t-ratio for $\alpha$ is measured as:

$$
t_{\alpha}=\hat{\alpha} /(\operatorname{se}(\hat{\alpha}))
$$

Where $\hat{\alpha}$ is the estimated parameter of $\alpha$, and $s e(\hat{\alpha})$ is the coefficient standard error.

Suppose, if the time series $y$ follows an AR (p) process then we test the below regression:

$$
\Delta z_{t}=\alpha z_{t-1}+y_{t}^{\prime} \delta+\beta_{1} \Delta z_{t-1}+\beta_{2} \Delta z_{t-2}+\cdots+\beta_{p} \Delta z_{t-p}+\vartheta_{t}
$$

4.2 Dickey-Fuller Test with GLS Detrending (DFGLS)

The quasi-difference of $z_{t}$ conditional on the value of ' $\mathrm{a}$ ' is defined as:

$$
d\left(z_{t} \mid a\right)= \begin{cases}z_{t} & \text { if } t=1 \\ z_{t}-a z_{t-1} & \text { if } t>1\end{cases}
$$

The OLS regression of the quasi-differenced data $d\left(z_{t} \mid a\right)$ on the quasi-differenced $d\left(y_{t} \mid a\right)$ is defined as below: 


$$
d\left(z_{t} \mid a\right)=d\left(y_{t} \mid a\right)^{\prime} \delta(a)+\eta_{t}
$$

Elliot, Rothenberg, and Stock (ERS) (1996) recommend the value of $a$ to be equal to $\bar{a}$ where:

$$
\bar{a}=\left\{\begin{array}{cc}
1-\frac{7}{T} & \text { if } y_{t}=\{1\} \\
1-\frac{13.5}{T} & \text { if } y_{t}=\{1, t\}
\end{array}\right.
$$

Now the GLS detrended data, $z_{t}^{d}$ can be defined as :

$$
z_{t}^{d}=z_{t}-y_{t}^{\prime} \hat{\delta}(\bar{a})
$$

In Dickey Fuller GLS test we substitute the $y_{t}^{d}$ for the original $y_{t}$ as mentioned in equation (7) to get,

$$
\Delta z_{t}^{d}=\alpha z_{t-1}^{d}+\beta_{1} \Delta z_{t-1}^{d}+\cdots+\beta_{p} \Delta z_{t-p}^{d}+\vartheta_{t}
$$

We further consider the t-ratio for $\widehat{\alpha}$ as mentioned in ADF test.

\subsection{The Phillips-Perron (PP) Test}

The Phillips and Perron (1988) method estimates the equation (4) of the Dickey Fuller test and is based on the test statistic as shown below:

$$
\tilde{t}_{\alpha}=t_{\alpha}\left(\frac{\gamma_{0}}{f_{0}}\right)^{\frac{1}{2}}-\frac{T\left(f_{0}-\gamma_{0}\right)(s e(\hat{\alpha}))}{2 f_{0}^{\frac{1}{2}} s}
$$

where $\hat{\alpha}$ is the estimate, and $t_{\alpha}$ the t-ratio of $\alpha, s e(\hat{\alpha})$ is coefficient standard error, and $s$ is the standard error of the test regression. In addition, $\gamma_{0}$ is a estimate of the error variance and $f_{0}$, is a residual estimator. It is important to note that the asymptotic distribution of the Phillips-Perron modified t-ratio is the same as that of the ADF statistic.

4.4 The Kwiatkowski, Phillips, Schmidt, and Shin (KPSS) Test

The Kwiatkowski et al. (1992) test assumes the series $z_{t}$ to be (trend-) stationary under the null. The KPSS statistic is defined based on the regression:

$$
z_{t}=y_{t}^{\prime} \delta+u_{t}
$$

The LM statistic is defined as:

$$
L M=\sum_{t} S(t)^{2} /\left(T^{2} f_{0}\right)
$$

where $f_{0}$, is an estimator of the residual spectrum at frequency zero and $\mathrm{S}(\mathrm{t})$ is a cumulative residual function:

based on the residuals $\hat{u}_{t}=z_{t}-y_{t}^{\prime} \hat{\delta}(0)$.

$$
S(t)=\sum_{r=1}^{t} \hat{u}_{r}
$$

\subsection{Elliot, Rothenberg, and Stock Point Optimal (ERS) Test}

The ERS test is based on the quasi-differencing regression as mentioned in equation (9) in which the residuals are defined as $\hat{\eta}_{t}=d\left(z_{t} \mid a\right)-d\left(y_{t} \mid a\right)^{\prime} \hat{\delta}(a)$, and let $\operatorname{SSR}(a)=\sum \hat{\eta}_{t}{ }^{2}(a)$ be the sum-of-squared residuals function. The ERS test statistic of the null that $\alpha=1$ against the alternative that $\alpha=\bar{a}$, is then defined as:

$$
P_{T}=(\operatorname{SSR}(\bar{a})-\bar{a} \operatorname{SSR}(1)) / f_{0}
$$

Where $f_{0}$, is an estimator of the residual spectrum at frequency zero.

\section{$4.6 \mathrm{Ng}$ and Perron (NP) Tests}

$\mathrm{Ng}$ and Perron (2001) construct four test statistics that depend upon the GLS detrended data. These test statistics are different forms of Phillips and Perron $Z_{\alpha}$ and $Z_{t}$ statistics, the $R_{1}$ statistic, and the ERS statistic. First, define the term:

$$
k=\sum_{t=2}^{T}\left(z_{t-1}^{d}\right)^{2} / T^{2}
$$

The modified statistics may then be written as,

$$
\begin{gathered}
M Z_{\alpha}^{d}=\left(T^{-1}\left(z_{T}^{d}\right)^{2}-f_{0}\right) /(2 k) \\
M Z_{t}^{d}=M Z_{\alpha} * M S B \\
M S B=\left(k / f_{0}\right)^{\frac{1}{2}}
\end{gathered}
$$




$$
M P_{T}^{d}=\left\{\begin{aligned}
\left(\bar{c}^{2} k-\bar{c} T^{-1}\left(z_{T}^{d}\right)^{2}\right) / f_{0}, & \text { if } y_{t}=\{1\} \\
\left(\bar{c}^{2} k+(1-\bar{c}) T^{-1}\left(z_{T}^{d}\right)^{2}\right) / f_{0}, & \text { if } y_{t}=\{1, t\}
\end{aligned}\right.
$$

where:

$$
\bar{c}=\left\{\begin{aligned}
-7, \text { if } y_{t} & =\{1\} \\
-13.5, \text { if } y_{t} & =\{1, t\}
\end{aligned}\right.
$$

The NP tests require a specification for $y_{t}$ and a choice of method for estimating $f_{0}$.

\section{Empirical Results}

In this section, we discuss the empirical results of the six different unit root tests that were employed in our paper to detect the random walk behaviour of the stock prices in the 10 emerging Asian stock markets under study. We also check the robustness of the unit root results by conducting the empirical tests during different sub sample periods. We perform the empirical analysis during the pre-crisis (2001-2007), crisis \& post crisis (2008-2015) and also during the overall sample period (2001-2015).

\subsection{Overall Sample Period (Jan 2001-Mar 2015)}

Table 2, Panel A: provides us with the 5 different unit root test results in sections with only Intercept and also with both Trend \& Intercept forms. First the Augmented Dickey-Fuller (ADF) Unit root test results shows that the t-test statistic is greater than the critical value at $1 \%$ level of significance at intercept level as well as both trend \& intercept forms due to which we fail to the reject the null hypothesis of Unit root in the 10 emerging Asian stock markets. Second, we conduct the Phillips \& Perron Unit root tests by including only Intercept and also both Trend \& Intercept in the test equation. We say that the logarithm of the daily stock prices do follow random walk during overall sample period by employing PP Unit root as we observe the Adjusted $\mathrm{t}$-stat is more than the critical value at $1 \%$ level of significance due to which we fail to reject the null hypothesis of Unit root. Third, we employ the Kwiatkowski-Phillips-Schmidt-Shin (KPSS) Unit root test by including only Intercept and also both Trend \& Intercept in the test equation. In both the cases we observe that the Lagrange Multiplier (LM) test statistic is more than the critical values due to which we reject the null hypothesis of stationary and conclude that these series are unit root non stationary except the Malaysian market. We find the series in Malaysian market is stationary at $1 \%$ level of significance when we include both trend \& Intercept in the test equation. Fourth, we have conducted Dickey-Fuller GLS (ERS) test and find that $t$-stat is more than the asymptotic critical values at $1 \%$ and hence we fail to reject the null hypothesis of unit root for all the stock markets except Taiwan market in Trend \& Intercept form. We find the series in Taiwan market has no unit root and hence it is stationary at 5\% level of significance in the Trend \& Intercept form. Fifth, we have performed Elliot-Rothenberg-Stock Point-Optimal (ERSPO) test and find that the calculated P-stat is more than the critical values at $1 \%$ level of significance and hence we fail to reject the null hypothesis of unit root for all the Asian stock market series except for Taiwan Market in Trend \& Intercept form. We find Taiwan market to be stationary at 5\% level of significance in trend\& Intercept form by way of ERSPO unit root test similar to the findings of Dickey-Fuller GLS (ERS) unit root test. Table 3, Panel A: shows the Ng-Perron Unit root test results for the overall sample period (2001-2015) and we find that the four $M Z_{a}, M Z_{t}, M S B, M P T$ test statistics to be more than the asymptotic critical values at $1 \%$ level of significance. We accept the null hypothesis that the series has unit root for all Asian stock markets except for Taiwan Stock market where we find that the series has no unit root at 5\% level of significance in Trend \& Intercept form. Table $4 \& 5$ presents the critical values of different unit root tests at $1 \%, 5 \%$ and $10 \%$ level of significance.

Hence during the overall sample period (2001-2015), we empirically find that the emerging Asian stock market series has unit root in both the intercept only and trend \& intercept forms by six different Unit root tests employed in our analysis except for Malaysian market (KPSS Test in Trend \& Intercept form) and Taiwan market (Dickey-Fuller GLS (ERS) test, Elliot-Rothenberg-Stock Point-Optimal test and Ng-Perron unit root in trend \& Intercept forms) where we find no unit root. Hence except for Malaysia and Taiwan stock markets, we say that logarithm of daily Asian stock market prices follow random walk and hence are weak form efficient.

\subsection{Pre-Crisis Period (Jan 2001-Dec 2007)}

Table 2, Panel B: provides us with the 5 different unit root test results in sections with only Intercept and also with both Trend \& Intercept forms during pre-crisis period. First we employ the Augmented Dickey-Fuller (ADF) Unit root test result, we find that the t-test statistic is greater than the critical value at $1 \%$ level of significance due to which we fail to the reject the null hypothesis of Unit root when we include only Intercept and both trend $\&$ intercept unit root test equation. We observe that the series has unit root and hence logarithm of stock prices 
follow random walk in all emerging Asian stock market under consideration as per ADF test. Second, we conduct the Phillips \& Perron Unit root tests by including only Intercept and also both Trend \& Intercept in the test equation. We say that the logarithm of the daily stock prices do follow random walk during sub sample pre-crisis period by employing PP Unit root as we observe the Adjusted $t$-stat is more than the critical value at $1 \%$ level of significance due to which we fail to reject the null hypothesis of Unit root. We also find the p-values to be insignificant for each Asian stock market under consideration. Third, we employ the Kwiatkowski-Phillips-Schmidt-Shin (KPSS) Unit root test by including only Intercept and also both Trend \& Intercept in the test equation. In both the cases we observe that the Lagrange Multiplier (LM) test statistic is more than the critical values due to which we reject the null hypothesis of stationary and conclude that these series are unit root non stationary. Fourth, we have conducted Dickey-Fuller GLS (ERS) test and find that t-stat is more than the asymptotic critical values at $1 \%$ and hence we fail to reject the null hypothesis of unit root for all the stock markets. Fifth, we have performed Elliot-Rothenberg-Stock Point-Optimal (ERSPO) test and find that the calculated P-stat is more than the critical values at $1 \%$ level of significance and hence we fail to reject the null hypothesis of unit root for all the Asian stock markets. Table 3, Panel B: shows the Ng-Perron Unit root test results for the sub-sample pre-crisis period (2001-2007) and we find the four $M Z_{a}, M Z_{t}, M S B, M P T$ test statistics to be more than the asymptotic critical values at $1 \%$ level of significance. Hence we accept the null hypothesis that the series has unit root for all Asian stock markets. Table $4 \& 5$ presents the critical values of unit root tests.

Hence during the sub-sample pre-crisis period (2001-2007), we empirically find that the emerging Asian stock market series has unit root in both the intercept only and trend \& intercept forms unanimously by six different Unit root tests employed in our analysis. Our test results show that during pre-crisis period all the Asian stock market prices follow random walk.

\subsection{Crisis \& Post-Crisis Period (Jan 2008- Mar 2015)}

Table 2, Panel C: provides us with the unit root test results in sections with only Intercept and also with both Trend \& Intercept forms for crisis \& post-crisis period. First, during this sub-sample period, we find that China \& Hongkong stock markets do not follow random walk in the Intercept form at $10 \%$ level of significance whereas India, Hongkong and Philippines do not follow random walk at 10\%, 5\%,5\% respectively in Trend \& Intercept form of the Augmented Dickey-Fuller (ADF) Unit root test. The rest of the Asian stock markets do follow random walk when we employ the ADF unit root test. Second, we conduct the Phillips \& Perron Unit root tests by including only Intercept and also both Trend \& Intercept in the test equation. Our test results show that China \& Hongkong stock markets do not follow random walk as the series has no unit root at $10 \%$ level of significance in Intercept form. Also we find that India, Hongkong and Philippines stock market series has no unit root and hence do not follow random walk at 10\%, 5\% and 5\% level of significance respectively in both Trend\& Intercept form. Third, we employ the Kwiatkowski-Phillips-Schmidt-Shin (KPSS) Unit root test by including only Intercept and also both Trend \& Intercept in the test equation. In both the cases we observe that the Lagrange Multiplier (LM) test statistic is more than the critical values due to which we reject the null hypothesis of stationary and conclude that these series are unit root non stationary and follow random walks except for China market in Intercept form and Hongkong \& Taiwan market in trend \& intercept forms where we find series to be stationary at $1 \%$ level of significance .Fourth, we have conducted Dickey-Fuller GLS (ERS) test and find that $\mathrm{t}$-stat is more than the asymptotic critical values at $1 \%$ and hence we fail to reject the null hypothesis of unit root for all the Asian stock markets. Fifth, we have performed Elliot-Rothenberg-Stock Point-Optimal (ERSPO) test and find that the calculated P-stat is more than the critical values at $1 \%$ level of significance and hence we fail to reject the null hypothesis of unit root for all the Asian stock markets. Table 3, Panel C: shows the $\mathrm{Ng}$-Perron Unit root test results for the sub-sample pre-crisis period (2008-2015) and we find the four $M Z_{a}, M Z_{t}, M S B, M P T$ test statistics to be more than the asymptotic critical values at $1 \%$ level of significance. Hence we accept the null hypothesis that the series has unit root for all Asian stock markets. Table $4 \& 5$ presents the critical values of different unit root tests at $1 \%, 5 \%$ and $10 \%$ level of significance.

Hence during the sub-sample period (2008-2015), we empirically find that the emerging Asian stock market series has unit root in both the intercept only and trend \& intercept forms by six different Unit root tests employed in our analysis except for China market (ADF,PP,KPSS Test in Intercept form), Hongkong market (ADF test and PP test in Intercept and both trend \& intercept forms, KPSS in Trend \& Intercept form), Indian market (ADF test and PP test in trend \& intercept form), Philippines market (ADF test and PP test in trend \& intercept form) and Taiwan market (KPSS in Trend \& Intercept form) where we find no unit root. Hence except for China, Hongkong, India, Philippines and Taiwan, we say that logarithm of daily Asian stock markets under consideration do follow random walk and hence are weak form efficient during the sub-sample period 
(2008-2015).

Table 2. Unit root test results of Asian stock market indices

\begin{tabular}{|c|c|c|c|c|c|c|c|c|c|c|}
\hline & \multicolumn{5}{|c|}{$\begin{array}{c}\text { INTERCEPT FORM } \\
\end{array}$} & \multicolumn{5}{|c|}{ TREND \& INTERCEPT FORM } \\
\hline & \multicolumn{10}{|c|}{ Panel A: Overall Sample Period (2001-2015) } \\
\hline & $\begin{array}{l}\text { ADF } \\
\text { ( } t \text { stat }) \\
\end{array}$ & $\begin{array}{l}\text { PP } \\
\text { (Adj t stat) }\end{array}$ & $\begin{array}{l}\text { KPSS } \\
\text { (LM stat) }\end{array}$ & $\begin{array}{l}\text { ERS DF } \\
\text { GLS } \\
\text { (t stat) } \\
\end{array}$ & $\begin{array}{l}\text { ERSPO } \\
\text { (P stat) }\end{array}$ & $\begin{array}{l}\text { ADF } \\
\text { (tstat) }\end{array}$ & $\begin{array}{l}\text { PP } \\
\text { (Adj t stat) }\end{array}$ & $\begin{array}{l}\text { KPSS } \\
\text { (LM stat) }\end{array}$ & $\begin{array}{l}\text { ERS DF } \\
\text { GLS } \\
\text { (t stat) } \\
\end{array}$ & $\begin{array}{l}\text { ERSPO } \\
\text { (P stat) } \\
\end{array}$ \\
\hline India & -0.6686 & -0.7071 & 6.9499 & 1.2911 & 113.7101 & -1.8303 & -1.8075 & 1.1774 & -1.7523 & 14.7139 \\
\hline China & -0.9057 & -1.0096 & 2.6586 & -0.8728 & 9.6323 & -1.6067 & -1.6951 & 0.5044 & -1.2379 & 26.245 \\
\hline Hongkong & -1.2632 & -1.2070 & 5.7984 & -0.9068 & 9.3296 & -2.8669 & -2.7956 & 0.5988 & -1.9762 & 11.7412 \\
\hline Taiwan & -2.0373 & -2.0101 & 4.9117 & -0.6371 & 13.2982 & -2.9991 & -2.9902 & 0.2477 & $-2.9876 * *$ & $5.1345 * *$ \\
\hline Malaysia & -1.0598 & -1.0275 & 7.2341 & 0.8187 & 80.9415 & -2.4511 & -2.5064 & $0.1821 *$ & -2.4352 & 7.6952 \\
\hline Thailand & -1.5985 & -1.6109 & 6.2809 & 0.8731 & 94.2809 & -2.2521 & -2.3584 & 0.4808 & -1.8106 & 13.2938 \\
\hline Pakistan & -1.0775 & -1.0857 & 6.3058 & 2.5605 & 296.6413 & -1.4316 & -1.5834 & 1.0752 & -1.1257 & 35.5287 \\
\hline Srilanka & -1.7693 & -1.7411 & 6.8613 & 2.2276 & 344.1819 & -1.5177 & -1.5875 & 0.6859 & -0.9962 & 31.2771 \\
\hline Indonesia & -1.1549 & -1.1398 & 7.4272 & 1.6192 & 200.4015 & -1.7051 & -1.5779 & 0.8607 & -1.8387 & 12.1544 \\
\hline \multirow[t]{2}{*}{ Philippines } & -0.1966 & -0.1034 & 7.2028 & 1.226 & 74.0855 & -2.8192 & -2.6829 & 0.2911 & -1.7256 & 15.0223 \\
\hline & \multicolumn{10}{|c|}{ Panel B: Pre-Crisis Period (2001-2007) } \\
\hline India & 1.3665 & 1.2655 & 4.9426 & 2.6597 & 122.2662 & -2.6494 & -2.5425 & 0.8097 & -0.4897 & 60.4641 \\
\hline China & 1.5859 & 1.5129 & 1.4039 & 0.8276 & 39.7701 & 0.2784 & 0.2912 & 0.9649 & 0.6143 & 121.9516 \\
\hline Hongkong & 0.7569 & 0.7221 & 3.8917 & 0.4105 & 25.7995 & -2.2281 & -2.2311 & 0.8667 & -0.2629 & 68.5145 \\
\hline Taiwan & -1.1062 & -1.2441 & 3.8062 & -0.2091 & 16.3461 & -2.6149 & -2.8317 & 0.3352 & -2.3165 & 8.5275 \\
\hline Malaysia & 0.2093 & 0.3388 & 4.5508 & 1.4335 & 51.7996 & -2.1837 & -2.1554 & 0.4318 & -1.4979 & 16.3092 \\
\hline Thailand & -1.0997 & -1.1217 & 4.7145 & 1.0679 & 94.8652 & -2.0929 & -2.1149 & 0.6739 & -2.0504 & 10.7944 \\
\hline Pakistan & -0.4247 & -0.4759 & 5.2247 & 2.5974 & 317.2606 & -1.9935 & -2.3062 & 0.7419 & -1.5666 & 18.0582 \\
\hline Srilanka & -1.2592 & -1.2627 & 4.9515 & 1.6571 & 227.7765 & -1.5525 & -1.5651 & 0.7854 & -1.7428 & 12.5173 \\
\hline Indonesia & 0.7979 & 0.9348 & 5.0576 & 2.7781 & 164.3472 & -2.3554 & -2.3088 & 0.6012 & -1.1072 & 26.1121 \\
\hline \multirow[t]{2}{*}{ Philippines } & 0.3263 & 0.3891 & 4.4711 & 0.9305 & 39.77405 & -2.2741 & -2.2296 & 0.8598 & -0.8822 & 39.3624 \\
\hline & \multicolumn{10}{|c|}{ Panel C: Crisis \& Post-Crisis Period (2008-2015) } \\
\hline India & -0.9656 & -0.8323 & 3.6066 & -1.0576 & 8.4014 & $-3.2937 * * *$ & $-3.1556 * * *$ & 0.2448 & -1.1815 & 27.9071 \\
\hline China & $-2.8335 * * *$ & $-2.8595 * * *$ & $0.6298 *$ & -0.4077 & 48.7051 & -2.4511 & -2.4789 & 0.3851 & -0.378 & 59.5483 \\
\hline Hongkong & $-2.5903 * * *$ & $-2.5779 * * *$ & 1.5141 & -1.2283 & 8.1276 & $-3.4782 * *$ & $-3.4367 * *$ & $0.1539 *$ & -1.5045 & 19.3395 \\
\hline Taiwan & -1.6753 & -1.6063 & 2.0622 & -1.5903 & 4.8405 & -2.4105 & -2.3798 & $0.1731 *$ & -1.6018 & 17.8068 \\
\hline Malaysia & -0.6948 & -0.6997 & 4.4943 & -0.6494 & 18.0261 & -2.6114 & -2.601 & 0.3382 & -1.0235 & 44.2122 \\
\hline Thailand & -0.7369 & -0.7563 & 4.533 & -0.4931 & 19.4243 & -2.3861 & -2.4124 & 0.3344 & -1.2115 & 31.5152 \\
\hline Pakistan & 0.6317 & 0.4397 & 4.6636 & 0.8334 & 45.9403 & -2.5826 & -2.7011 & 0.7641 & -0.4842 & 83.1065 \\
\hline Srilanka & -0.9854 & -0.9353 & 3.7741 & 0.8509 & 105.8695 & -0.9325 & -1.0413 & 0.7996 & -0.9916 & 42.2566 \\
\hline Indonesia & -0.7814 & -0.7003 & 4.5384 & -0.2899 & 23.9136 & -2.2325 & -2.1275 & 0.4437 & -1.3656 & 24.4906 \\
\hline Philippines & -0.2898 & -0.1035 & 5.158 & 0.1913 & 33.0413 & $-3.5848 * *$ & $-3.6846 * *$ & 0.2799 & -1.1307 & 35.3803 \\
\hline
\end{tabular}


Table 3. Ng Perron unit root test results of Asian stock market indices

\begin{tabular}{|c|c|c|c|c|c|c|c|c|}
\hline & \multicolumn{4}{|c|}{ INTERCEPT FORM } & \multicolumn{4}{|c|}{ TREND \& INTERCEPT FORM } \\
\hline & \multicolumn{8}{|c|}{ Panel A: Overall Sample Period (2001-2015) } \\
\hline & MZa & MZt & MSB & MPT & MZa & MZt & MSB & MPT \\
\hline India & 1.0000 & 1.2929 & 1.2929 & 112.3080 & -6.1922 & -1.7526 & 0.2830 & 14.7142 \\
\hline China & -2.2508 & -0.8727 & 0.3877 & 9.6283 & -3.3450 & -1.2375 & 0.3700 & 26.1663 \\
\hline Hongkong & -2.3757 & -0.9067 & 0.3816 & 9.2919 & -7.8143 & -1.9744 & 0.2527 & 11.6679 \\
\hline Taiwan & -1.3946 & -0.6376 & 0.4572 & 13.1596 & $-17.933 * *$ & $-2.985 * *$ & $0.166 * *$ & $5.137 * *$ \\
\hline Malaysia & 0.7332 & 0.8134 & 1.1094 & 79.9309 & -12.2027 & -2.4294 & 0.1991 & 7.6974 \\
\hline Thailand & 0.7244 & 0.8735 & 1.2059 & 92.9983 & -6.9159 & -1.8092 & 0.2616 & 13.2467 \\
\hline Pakistan & 1.2385 & 2.5659 & 2.0717 & 291.7130 & -2.5582 & -1.1263 & 0.4403 & 35.4456 \\
\hline Srilanka & 0.9751 & 2.2341 & 2.2911 & 335.8510 & -2.5508 & -0.9980 & 0.3913 & 31.0746 \\
\hline Indonesia & 0.9228 & 1.6178 & 1.7533 & 197.3220 & -7.7115 & -1.8355 & 0.2380 & 12.1549 \\
\hline \multirow[t]{2}{*}{ Philippines } & 1.2239 & 1.2262 & 1.0018 & 73.3691 & -6.1017 & -1.7265 & 0.2830 & 14.9242 \\
\hline & \multicolumn{8}{|c|}{ Panel B: Pre-Crisis Period (2001-2007) } \\
\hline India & 2.2608 & 2.6803 & 1.1856 & 120.3320 & -0.9180 & -0.4880 & 0.5316 & 58.4678 \\
\hline China & 1.1711 & 0.8282 & 0.7072 & 39.6949 & 0.8620 & 0.6151 & 0.7136 & 120.0310 \\
\hline Hongkong & 0.7291 & 0.4108 & 0.5634 & 25.7888 & -0.4707 & -0.2623 & 0.5573 & 66.8664 \\
\hline Taiwan & -0.4531 & -0.2090 & 0.4613 & 16.0729 & -10.9057 & -2.3098 & 0.2118 & 8.4881 \\
\hline Malaysia & 1.8929 & 1.4440 & 0.7628 & 50.9221 & -5.5295 & -1.4970 & 0.2707 & 16.1031 \\
\hline Thailand & 0.9085 & 1.0691 & 1.1768 & 92.4558 & -8.4783 & -2.0459 & 0.2413 & 10.7952 \\
\hline Pakistan & 1.2143 & 2.6000 & 2.1412 & 309.5420 & -5.0541 & -1.5647 & 0.3096 & 17.9194 \\
\hline Srilanka & 0.8958 & 1.6640 & 1.8576 & 219.3190 & -7.5837 & -1.7494 & 0.2307 & 12.4934 \\
\hline Indonesia & 1.9707 & 2.7940 & 1.4178 & 160.9240 & -3.1648 & -1.1092 & 0.3505 & 25.6123 \\
\hline \multirow[t]{2}{*}{ Philippines } & 1.3589 & 0.9375 & 0.6899 & 39.3655 & -2.0024 & -0.8808 & 0.4399 & 38.5241 \\
\hline & \multicolumn{8}{|c|}{ Panel C: Crisis \& Post-Crisis Period (2008-2015) } \\
\hline India & -2.8017 & -1.0605 & 0.3785 & 8.4001 & -3.1522 & -1.1831 & 0.3753 & 27.2940 \\
\hline China & -0.4215 & -0.4075 & 0.9667 & 47.2739 & -0.7253 & -0.3775 & 0.5205 & 58.1713 \\
\hline Hongkong & -3.0756 & -1.2276 & 0.3991 & 7.9465 & -4.7579 & -1.5027 & 0.3158 & 18.9156 \\
\hline Taiwan & -5.0816 & -1.5900 & 0.3129 & 4.8323 & -5.1644 & -1.6020 & 0.3102 & 17.6256 \\
\hline Malaysia & -1.1342 & -0.6542 & 0.5768 & 18.0165 & -2.0976 & -1.0239 & 0.4882 & 43.4345 \\
\hline Thailand & -0.8544 & -0.4931 & 0.5772 & 19.3366 & -2.9342 & -1.2107 & 0.4126 & 31.0398 \\
\hline Pakistan & 1.0775 & 0.8369 & 0.7767 & 45.6502 & -0.7562 & -0.4848 & 0.6411 & 80.3886 \\
\hline Srilanka & 0.6649 & 0.8513 & 1.2804 & 102.5770 & -2.0753 & -0.9892 & 0.4767 & 42.2352 \\
\hline Indonesia & -0.4698 & -0.2946 & 0.6272 & 23.6836 & -3.7523 & -1.3659 & 0.3640 & 24.2308 \\
\hline Philippines & 0.2758 & 0.1926 & 0.6982 & 32.7648 & -2.6105 & -1.1303 & 0.4330 & 34.4741 \\
\hline
\end{tabular}

Table 4. Critical values of ADF, PP, KPSS, ERS DF GLS, ERSPO Unit tests during different sub sample periods

\begin{tabular}{|c|c|c|c|c|c|c|c|c|c|c|c|}
\hline & & \multicolumn{5}{|c|}{ INTERCEPT FORM } & \multicolumn{5}{|c|}{ TREND \& INTERCEPT FORM } \\
\hline & & $\begin{array}{c}\text { ADF } \\
\text { ( t stat) }\end{array}$ & $\begin{array}{c}\text { PP } \\
\text { (Adj t stat) }\end{array}$ & $\begin{array}{c}\text { KPSS } \\
\text { ( LMstat) }\end{array}$ & $\begin{array}{c}\text { ERS DF GLS } \\
\text { (t stat) }\end{array}$ & $\begin{array}{l}\text { ERSPO } \\
\text { (P stat) } \\
\end{array}$ & $\begin{array}{c}\text { ADF } \\
\text { (t stat) }\end{array}$ & $\begin{array}{c}\text { PP } \\
\text { (Adj t stat) }\end{array}$ & $\begin{array}{c}\text { KPSS } \\
\text { ( LMstat) }\end{array}$ & $\begin{array}{c}\text { ERS DF GLS } \\
\text { ( } \mathrm{t} \text { stat })\end{array}$ & $\begin{array}{l}\text { ERSPO } \\
\text { (P stat) }\end{array}$ \\
\hline \multirow{3}{*}{$\begin{array}{c}\text { Overall Sample } \\
\text { Period (2001-2015) }\end{array}$} & $1 \%$ level & -3.431 & -3.433 & 0.739 & -2.565 & 1.990 & -3.960 & -3.960 & 0.216 & -3.480 & 3.960 \\
\hline & $5 \%$ level & -2.862 & -2.862 & 0.463 & -1.940 & 3.260 & -3.411 & -3.411 & 0.146 & -2.890 & 5.620 \\
\hline & $10 \%$ level & -2.567 & -2.567 & 0.347 & -1.616 & 4.480 & -3.127 & -3.127 & 0.119 & -2.570 & 6.890 \\
\hline \multirow{3}{*}{$\begin{array}{l}\text { Pre- Crisis Period } \\
\quad(2001-2007)\end{array}$} & $1 \%$ level & -3.433 & -3.433 & 0.739 & -2.566 & 1.990 & -3.963 & -3.963 & 0.216 & -3.480 & 3.960 \\
\hline & $5 \%$ level & -2.862 & -2.862 & 0.463 & -1.941 & 3.260 & -3.412 & -3.412 & 0.146 & -2.890 & 5.620 \\
\hline & $10 \%$ level & -2.567 & -2.567 & 0.347 & -1.616 & 4.480 & -3.128 & -3.128 & 0.119 & -2.570 & 6.890 \\
\hline \multirow{3}{*}{$\begin{array}{l}\text { Crisis \& } \\
\text { Post-Crisis Period } \\
(2008-2015)\end{array}$} & $1 \%$ level & -3.433 & -3.433 & 0.739 & -2.566 & 1.990 & -3.962 & -3.962 & 0.216 & -3.480 & 3.960 \\
\hline & $5 \%$ level & -2.862 & -2.862 & 0.463 & -1.940 & 3.260 & -3.412 & -3.412 & 0.146 & -2.890 & 5.620 \\
\hline & $10 \%$ level & -2.567 & -2.567 & 0.347 & -1.616 & 4.480 & -3.128 & -3.128 & 0.119 & -2.570 & 6.890 \\
\hline \multicolumn{12}{|c|}{$\begin{array}{l}\text { ADF -Augmented Dickey-Fuller test , PP-Phillips-Perron test, KPSS-Kwiatkowski-Phillips-Schmidt-Shin test, ERS DF GLS - Dickey-Fuller GLS (ERS) test, } \\
\text { ERSPO - Elliot-Rothenberg-Stock Point-Optimal test. } \\
\text { Source: Developed by authors. }\end{array}$} \\
\hline
\end{tabular}

Table 5. Asymptotic critical values of MZa, MZt,MSB,MPT tests of Ng-Perron unit root tests

\begin{tabular}{crr}
\hline & INTERCEPT FORM & TREND \& INTERCEPT FORM \\
\hline During all Sample & $1 \%-13.8000,-2.58000,0.17400,1.78000$ & $1 \%-23.8000,-3.42000,0.14300,4.03000$ \\
Periods & $5 \%-8.10000,-1.98000,0.23300,3.17000$ & $5 \%-17.3000,-2.91000,0.16800,5.48000$ \\
& $10 \%-5.70000,-1.62000,0.27500,4.45000$ & $10 \%-14.2000,-2.62000,0.18500,6.67000$ \\
\hline
\end{tabular}

Source: Developed by authors. 


\section{Conclusion}

This paper examines empirically on whether the important emerging Asian stock markets follow random walk or not. A market will be weak form efficient if the stock markets follow random walk. We performed six different unit root tests in intercept as well as trend \& intercept forms of unit root equations on 10 emerging Asian stock markets for different time periods to carry out the robustness check in our analysis. The analysis of random walk tests at different time periods before and after the global financial crisis 2008 is particularly relevant to understand how the Asian stock markets movements have been impacted by the crisis.

Our empirical findings show that firstly, during the overall sample period (2001-2015) except for Malaysia and Taiwan stock markets, the test results find the evidence of unit root i.e. random walk movement in 8 Asian stock markets. Hence 8 out of 10 Asian stock markets are weak form efficient during the period 2001-2015. Secondly, during the sub-sample pre-crisis period (2001-2007), our test results show that all the 10 Asian stock markets has unit root in the series. Hence we find all the 10 Asian stock markets are weak form efficient and follow random walk. Thirdly, during the crisis \& post-crisis period (2008-2015) except for China, Hongkong, India, Philippines and Taiwan, we find the presence of unit root for the rest of the markets. Hence only 5 out of 10 Asian stock markets are weak form efficient and follow random walk. Thus in our analysis we find evidence that global financial crisis does had an impact on the movement of important Asian stock market prices.

\section{References}

Amer, S., Ghulam, M., Qamar, H., \& Azeem, M. (2014). Efficiency of South Asian capital markets: An empirical analysis. European Journal of Business and Management, 6(11), 30-33.

Ashutosh, V. (2005). The study of the weak form informational efficiency in Bombay Stock Market. Finance India, 19(4), 1421-1424.

Asma, M., Mollah, A. S., \& Bhuyan, R. (2008). Market Efficiency in Emerging Stock Market: Evidence from Bangladesh. Journal of Emerging Market Finance, 7(1), 17-41. https://doi.org/10.1177/097265270700700102

Bachelier, L. (1900). Theorie de la Speculation. Annales Scientifiques de l'Ecole Normale Superieure, 3(17), 21-86.

Balkiz, O. (2003). Testing Informational Market Efficiency on Kuala Lumpur Stock Exchange. Jurnal Ekonomi Malaysia, 37, 3-20.

Chaudhuri. S. K. (1991). Short-run Share Price Behaviour: New Evidence on Weak Form of Market Efficiency. Vikalpa, 16(4), 17-21. https://doi.org/10.1177/0256090919910402

Cooray, A. V., \& Wickremasinghe, G. (2007). Efficiency of Emerging Stock Markets: Some Empirical Evidence from the South Asian Region. Journal of Developing Areas, 41(1), 171-183. https://doi.org/10.1353/jda.2008.0030

Cowles, A. (1933). Can stock market forecasters forecast? Econometrica, 1(3), 309-324. https://doi.org/10.2307/1907042

Dickey, D., \& Fuller, W. A. (1979). Distribution of the estimates for autoregressive time series with a unit root. Journal of the American Statistical Association, 74(366), 427-431. https://doi.org/10.2307/2286348

Elliot, G., Rothenberg, T. J., \& Stock, J. H. (1996). Efficient Tests for an Autoregressive Unit Root. Econometrica, 64(4), 813-836. https://doi.org/10.2307/2171846

Fama, E. F. (1970). Efficient capital markets: A review of theory and empirical work. Journal of Finance, 25(2), 383-417. https://doi.org/10.2307/2325486

Gupta, R., \& Basu, P. (2007). Weak-Form Efficiency In Indian Stock Markets. International Business and Economic Research Journal, 6(3), 57-64.

Hamid, K., Suleman, M. T., Ali, S. S. Z., \& Akash, R. S. (2010). Testing the weak form of efficient market hypothesis: Empirical evidence from Asia-pacific markets. International Research Journal of Finance and Economics, 58, 121-133.

Islam, S., Watanapalachaikul, S., \& Clark, C. (2007). Some Tests of the Efficiency of the Emerging Financial Markets: An Analysis of the Thai Stock Market. Journal of Emerging Market Finance, 6(3), 291-302. https://doi.org/10.1177/097265270700600304

Kwiatkowski, D., Phillips, P. C. B., Schmidt, P., \& Shin, Y. (1992). Testing the null hypothesis of stationarity 
against the alternative of a unit root. Journal of Econometrics, 54(1-3), 159-178. https://doi.org/10.1016/0304-4076(92)90104-Y

Laurence, M., Francisc, C., \& Sun, Q. (1997). Weak-Form Market efficiency and Causality Test in Chinese Stock Markets. Multinational Finance Journal, 1(4), 291-307. https://doi.org/10.17578/1-4-3

Malkiel, B. (1992). Efficient market hypothesis. In P. Newman, M. Milgate, \& J. Eatwell (Eds.), New Palgrave Dictionary of Money and Finance. Macmillan,London.

Mishra, P. K. (2009). Capital Market Efficiency and Financial Innovation - A Perspective Analysis. The Research Network, 4(1), 1-4.

Mishra, P. K. (2012). Efficiency of South Asian capital markets. Pakistan Journal of Commerce and Social Sciences, 6(1), 27-34.

Ng, S., \& Perron, P. (2001). Lag Length Selection and the Construction of Unit Root Tests with Good Size and Power. Econometrica, 69(6), 1519-1554. https://doi.org/10.1111/1468-0262.00256

Nisar, S., \& Muhammed, H. (2012). Testing weak form of efficient market hypothesis: Empirical evidence from South-Asia. World Applied Sciences Journal, 17(4), 414-427.

Paulo, V. (2013). The Efficiency of Asian Stock Markets: A Weak-Form Efficiency analysis. IJER, 1O(1), 117-136.

Phillips, P. C. B., \& Perron, P. (1988). Testing for a Unit Root in Time Series Regression. Biometrika, 75(2), 335-346. https://doi.org/10.1093/biomet/75.2.335

Poshakwale, S. (1996). Evidence on Weak Form Efficiency and Day of the Week Effect in the Indian Stock Market. Finance India, 10(3), 605-616.

Worthington, A. C., \& Higgs, H. (2004). Random Walks and Market Efficiency in European Equity Markets. Global Journal of Finance and Economics, 1(1), 59-78.

\section{Copyrights}

Copyright for this article is retained by the author(s), with first publication rights granted to the journal.

This is an open-access article distributed under the terms and conditions of the Creative Commons Attribution license (http://creativecommons.org/licenses/by/4.0/). 